\title{
Does Human Resource Management Help a Company's Financial Operating Result?
}

\author{
Rob. C. H. van Otterlo \\ Faculty of Law, University of Amsterdam, Amsterdam, Netherlands. \\ Email: robvanotterlo@icloud.com \\ Received October $2^{\text {nd }}, 2013$; revised November $1^{\text {st }}, 2013$; accepted November $25^{\text {th }}, 2013$
}

Copyright (C) 2013 Rob. C. H. van Otterlo. This is an open access article distributed under the Creative Commons Attribution License, which permits unrestricted use, distribution, and reproduction in any medium, provided the original work is properly cited. In accordance of the Creative Commons Attribution License all Copyrights (C) 2013 are reserved for SCIRP and the owner of the intellectual property Rob. C. H. van Otterlo. All Copyright (C) 2013 are guarded by law and by SCIRP as a guardian.

\begin{abstract}
Human Resource Management (HRM) is widely believed to have a positive effect on the performance of company. However, empirical proof of this is hard to come by. In this study, we try to establish a linkage between HRM and financial output of two case studies in the profit sector. To do this, we have developed a performance measurement system that is tailored to the specific needs of measuring HRM-performance in for-profit of company. Although we do not try to generalize the outcome of this study, it looks promising in the way that more case studies should be conducted using this specific performance measurement system. If nothing else, management and controllers could use the system to evaluate the performance of their HRM-tools.
\end{abstract}

Keywords: HRM; Return on Investment; Finance

\section{Introduction}

As HRM has become increasingly popular in management ranks, there are growing calls to make HRM efforts measurable and thus subject to direction. Several HRM theories associate HRM performance and organisational performance with each other. They assume, based on empirical research or not, that HRM has a positive impact on a company's operating result. Up to now, however, the "evidence" that HRM has a positive impact on the operating result has often been insufficiently "hard". This article presents a theoretical model which partly fills this "gap" in the literature. We wish to answer the question: are the effects of HRM measurable and can they be assessed quantitatively?

We also hope that the model will furnish a practical tool enabling controllers to measure the effect of HRM in companies. Based on such effectiveness measurements, a controller can advise the board and HR manager on how best to manage the company to optimise the HRM efforts. In this manner, HRM should be able to make a useful contribution to the particular organisation's bottom-line objectives.

\section{Structure of This Article}

In Sections 3 and 4, we will start with a brief overview of the various research schools regarding HRM performance measurement. After this, in Sections 5 through 9, we will present our performance measurement model, which relates to measuring a business's general performance, and then, in Sections 10 and 11, we will present the specific HRM performance measurement model. Next, we will offer specific recommendations in Section 12 on how controllers and management might use the model in practice, and, finally, in Section 13, we will make some concluding remarks.

\section{HRM in Relation to Performance}

The relationship between HRM and performance has been the subject of a growing number of studies during the past thirty years, particularly in the English-speaking world. Dutch researchers have shown increased interest in this theme as well [1-5].

HRM also appears to be gaining ground as an operational issue meriting attention by management. More and more, the HRM departments within large companies are 
being led by a director or manager who is a top executive at the organisation. These departments thereby have a greater interest in making clear the part HRM plays in the overall business operations. The time seems ripe for no longer being satisfied with implicit assumptions about HRM/PM's impact on the company's operating result, but instead, to start searching for empirically-supported HRM performance theories which are as explicit as possible.

\section{Performance Theories}

It is generally assumed today that there is a positive relationship between HRM and corporate performance [6-9]. There are various theories, however, concerning the way in which PM supposedly affects a company's operating result.

Three major schools of thought are reflected in Table 1:

These actually represent three HRM performance approaches: 1) strategic fit; 2) broad HRM approach with implicit assumptions about HRM performance and 3) normative theory. None of these schools, however, has been successful to now in providing sufficiently hard evidence demonstrating the connection between HRM and company performance. In this connection, Guest has stated, "There may be an association between HRM practices and company profit (one of the potential corporate objectives, $\mathrm{RvO}$ ), but without some linkages (between the performance indicators, $\mathrm{RvO}$ ), we will not know why: we have no theory."'[10]

\section{Company Performance: A Model}

The research described here provides a model for testing the effects of HRM policy against the operating results.

This article is limited to for-profit organisations. All the models and performance indicators presented in this article have been derived from a previous case study [11].

Figure 1 shows in diagram form how, under our model, the effectiveness performance measurement is ultimately determined. The operating result is assessed based on a number of characteristics which, after being multiplied by a weight, are clustered into effectiveness criteria. In this manner, operating results within the same sector can be compared to one another.

\section{The Performance Measurement Model}

In order to ultimately measure the performance of personnel management in practice, we developed a theoretical model, which can be tested empirically [11].

The model includes five "effectiveness criteria", namely, financial added value; efficiency; needs met; self-maintenance and satisfaction. These effectiveness criteria in turn consist of 21 performance indicators, the "effectiveness characteristics". Effectiveness criteria and characteristics must be formulated differently for each industry and/or company. The effectiveness criteria and characteristics from which they are composed, as used in the empirical study mentioned earlier, are shown in Table 2.

In terms of business operations, these characteristics will not all have the same importance in every instance. To assign a weight to these now, we asked 12 industry experts to assign a value to each characteristic for purposes of the case studies.

The 12 experts evaluated the different effectiveness criteria on a scale of $1-5\{1=$ irrelevant; $2=$ unimpor$\operatorname{tant} ; 3=$ neutral; $4=$ important; $5=$ very important $\}$ with regard to their perceived importance for their organisations' business operations [11]. The results shown in Table 2 are rounded-off averages.

Table 1. HRM schools.

\begin{tabular}{|c|c|c|}
\hline "School" & Theory & $\begin{array}{l}\text { Performance definition } \\
\text { assumption/hypothesis }\end{array}$ \\
\hline $\begin{array}{l}\text { Hendry \& Pettigrew; Miles \& } \\
\text { Snow; Schuler \& Jackson. } \\
\text { ("Strategic Theory", Michigan } \\
\text { model) }\end{array}$ & $\begin{array}{l}\text { Focuses on strategy: the relationship between possible } \\
\text { external, uncertain factors and HRM policy and practice. }\end{array}$ & $\begin{array}{l}\text { A good "fit" between HRM and its } \\
\text { context (corporate strategy and corporate } \\
\text { structure) results in superior } \\
\text { "performance". Performance is defined } \\
\text { primarily in financial terms. }\end{array}$ \\
\hline $\begin{array}{l}\text { Beer; Kochan; Katz \& McKersie. } \\
\text { ('Descriptive Theory', Harvard } \\
\text { model) }\end{array}$ & $\begin{array}{l}\text { Broad HRM approach. Very general specification of the HRM } \\
\text { field and the related outcomes. Strong focus on the different } \\
\text { interests of employees in organisations. }\end{array}$ & $\begin{array}{l}\text { No clear picture of the relationship } \\
\text { between HRM and performance. }\end{array}$ \\
\hline $\begin{array}{l}\text { Walton; Lawler; Pfeffer; Guest. } \\
\text { ("Normative Theory") }\end{array}$ & $\begin{array}{l}\text { Normative. Based on "best practices", and implies "one best } \\
\text { way". } \\
\text { - }\end{array}$ & $\begin{array}{l}\text { If an integrated 'set' of HRM practices } \\
\text { (best practices) focuses on the normative } \\
\text { objectives commitment, quality and } \\
\text { flexibility, employees will automatically } \\
\text { perform better, resulting in better } \\
\text { organisational performance. }\end{array}$ \\
\hline
\end{tabular}




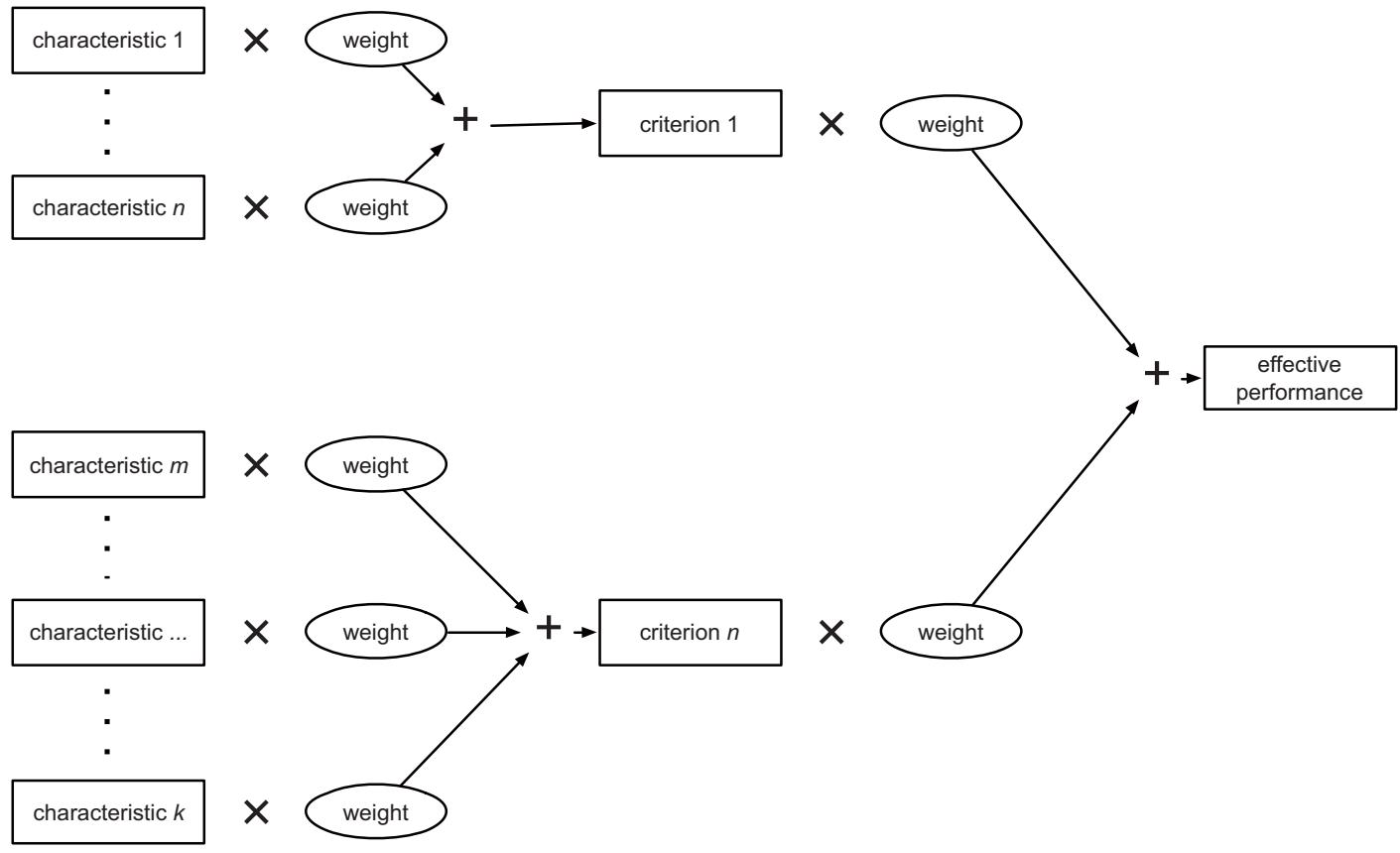

Figure 1. Interrelationship between effectiveness characteristic scores.

Table 2. Effectiveness criteria, characteristics and assigned weights.

\begin{tabular}{|c|c|c|}
\hline Effectiveness criterion & Characteristic & Weight \\
\hline \multicolumn{3}{|l|}{ Financial added value } \\
\hline & Return on Assets & \\
\hline & (ROA) & 5 \\
\hline & Labour ratio & 4 \\
\hline & Market share & 4 \\
\hline \multicolumn{3}{|l|}{ Efficiency } \\
\hline & Days of receivables outstanding & 4 \\
\hline & Turnover rate & 4 \\
\hline & ISO certification & 4 \\
\hline & Assessment standard & 3 \\
\hline \multicolumn{3}{|l|}{ Needs met } \\
\hline & Competitive price & 4 \\
\hline & Customer satisfaction & 5 \\
\hline & Delivery reliability & 5 \\
\hline & Just-In-Time deliveries & 5 \\
\hline & ISO certification & 4 \\
\hline \multicolumn{3}{|l|}{ Self-maintenance } \\
\hline & Organisational adjustment & 4 \\
\hline & Career management & 4 \\
\hline & New products & 4 \\
\hline & New services & 3 \\
\hline \multicolumn{3}{|l|}{ Satisfaction } \\
\hline & Salary & 4 \\
\hline & Career management & 4 \\
\hline & Quality system & 4 \\
\hline & Occupational health and safety annual plan & 4 \\
\hline & Absenteeism & 4 \\
\hline
\end{tabular}




\section{Nominal and Scalar Effectiveness Characteristics}

We have used nominal and scalar effectiveness characteristics in our model. Nominal characteristics are attributes in which the values are derived from categories, such as: salary in/not in accordance with collective labour agreement scheme and client satisfied/not satisfied. Scalar characteristics are attributes in which the values are expressed as quantities, such as: stock turnover rate or number of days absent per year on account of illness.

The values for the nominal characteristics are determined by scoring each characteristic as yes/no or none (or no)/present. For example: having ISO certification (yes) generates 1 point; the lack of ISO certification (no) generates 0 points. Note that, in our case, not having ISO certification generates a neutral score of 0 and not, for instance, -1 , because, within the cases and industry examined by us, the benchmark for ISO certification is not having this [11]! Of course, the values for the characteristics may be different for each industry, and these will have to be determined through research. A benchmark must also be established for each characteristic. That is, per characteristic, it must be ascertained, based on research and/or literature, what a more or less "normal score" is for that specific characteristic [11].

Table 3 provides an overview of all the nominal characteristics utilised by us, along with the scores applicable to the industry examined by us.

Table 3. Nominal characteristics and related scores.

\begin{tabular}{|c|c|c|c|}
\hline Characteristic & Value & Rank & Score \\
\hline \multicolumn{4}{|l|}{ ISO Certification } \\
\hline \multirow[t]{3}{*}{ ISO Certification (Efficiency) } & None & normal & 0 \\
\hline & ISO & & \\
\hline & certification & over & 1 \\
\hline \multirow[t]{2}{*}{ Salary in accordance with } & Collective labour agreement & normal & 0 \\
\hline & Collective labour agreement plus & over & 1 \\
\hline \multirow[t]{3}{*}{ Career management } & None & normal & 0 \\
\hline & Present & over & 1 \\
\hline & With MD & excellent & 2 \\
\hline \multirow[t]{2}{*}{ Working conditions } & No occupational health and safety plan & under & -1 \\
\hline & In accordance with occupational health and safety plan & normal & 0 \\
\hline \multirow[t]{3}{*}{ Quality system } & None & normal & 0 \\
\hline & Present & over & 1 \\
\hline & Present and ISO & excellent & 2 \\
\hline \multirow[t]{2}{*}{ Customer satisfaction } & No & under & -1 \\
\hline & Yes & normal & 0 \\
\hline \multirow[t]{2}{*}{ Delivery reliability } & No & under & -1 \\
\hline & Yes & normal & 0 \\
\hline \multirow[t]{2}{*}{ Just-In-Time deliveries } & No & under & -1 \\
\hline & Yes & normal & 0 \\
\hline \multirow[t]{2}{*}{ Competitive price } & No & under & -1 \\
\hline & Yes & normal & 0 \\
\hline ISO certification & No & normal & 0 \\
\hline (Needs met) & Yes & over & 1 \\
\hline \multirow[t]{3}{*}{ Market share } & Decrease & under & -1 \\
\hline & Constant & normal & 0 \\
\hline & Increase & over & 1 \\
\hline \multirow[t]{2}{*}{ New products } & No & under & -1 \\
\hline & Yes & normal & 0 \\
\hline \multirow[t]{2}{*}{ New services } & No & under & -1 \\
\hline & Yes & normal & 0 \\
\hline \multirow[t]{2}{*}{ Organisational adjustment } & No & under & -1 \\
\hline & Yes & normal & 0 \\
\hline
\end{tabular}


The values of the scalar characteristics are determined by scoring each characteristic beforehand as to its specific performance falling within a ranking order. This specific performance is measured against the benchmark applicable to that characteristic. The ranking order is shown in Table 4.

The score for the various scalar characteristics is determined based on a benchmark (this is also true, by the way, for the nominal characteristics) [11]. The following items are examined for each characteristic:

- What constitutes a "normal" score within the industry concerned?

- What are the worst and best realistic scores within the industry concerned, in other words: What is the lower limit and upper limit for each characteristic?

To give two examples: Within the industry examined by us, Return on Assets, or ROA, is a scalar characteristic. ROA is expressed as a percentage. The scores associated with the scalar categories in this case are as follows (Table 5).

If we look, for example, at the characteristic days of receivables outstanding (see Table 6), then the benchmark is 30 days (this is the payment period which suppliers themselves utilise in their delivery conditions) [11]. Excellent performance is achieved with a score of less than 20 days, while more than 45 days results in a bad performance score. We score all scalar characteristics in this manner.

Table 6 sets forth all the scalar characteristics used by us.

\section{Calculation of Overall Performance}

We cannot regard the total score as an absolute value, but must see it as an indication on a standard range made up of two hypothetical extremes, namely, the bad performer and the excellent performer (see Table 7) in the business sector. The total score is thus standardised and results in a figure between $-100 \%$ and $+100 \%$. Table 7 shows the effectiveness performance classes in which an operating

Table 4. Ranking order for scalar categories.

\begin{tabular}{|c|c|c|c|c|}
\hline $\begin{array}{c}\text { Least } \\
\text { important }\end{array}$ & under & normal & over & $\begin{array}{c}\text { Most } \\
\text { important }\end{array}$ \\
\hline bad & & & & excellent \\
\hline-2 & -1 & 0 & 1 & 2 \\
\hline
\end{tabular}

Table 5. ROA scores for scalar categories.

\begin{tabular}{ccccc}
\hline Characteristic & Lower limit & Upper limit & Rank & Score \\
\hline ROA & - & $6 \%$ & bad & -2 \\
& $6 \%$ & $9 \%$ & under & -1 \\
& $9 \%$ & $12 \%$ & normal & 0 \\
& $12 \%$ & $20 \%$ & over & 1 \\
& $20 \%$ & - & excellent & 2 \\
\hline
\end{tabular}

Table 6. Scalar characteristics and related scores.

\begin{tabular}{|c|c|c|c|c|}
\hline Characteristic & $\begin{array}{l}\text { Lower } \\
\text { limit }\end{array}$ & Upper limit & Rank & Score \\
\hline \multirow[t]{5}{*}{ ROA } & - & $6 \%$ & bad & -2 \\
\hline & $6 \%$ & $9 \%$ & under & -1 \\
\hline & $9 \%$ & $12 \%$ & normal & 0 \\
\hline & $12 \%$ & $20 \%$ & over & 1 \\
\hline & $20 \%$ & - & excellent & 2 \\
\hline \multirow[t]{5}{*}{ Labour ratio } & & $45 \%$ & excellent & 2 \\
\hline & $45 \%$ & $48 \%$ & over & 1 \\
\hline & $48 \%$ & $52 \%$ & normal & 0 \\
\hline & $52 \%$ & $55 \%$ & under & -1 \\
\hline & $55 \%$ & - & bad & -2 \\
\hline \multirow[t]{5}{*}{ Stock turnover rate } & & 2 & bad & -2 \\
\hline & 2 & 3.15 & under & -1 \\
\hline & 3.15 & 3.85 & normal & 0 \\
\hline & 3.85 & 4.5 & over & 1 \\
\hline & 4.5 & - & excellent & 2 \\
\hline \multirow[t]{5}{*}{$\begin{array}{c}\text { Days of receivables } \\
\text { outstanding }\end{array}$} & - & 20 & excellent & 2 \\
\hline & 20 & 27 & over & 1 \\
\hline & 27 & 33 & normal & 0 \\
\hline & 33 & 45 & under & -1 \\
\hline & 45 & - & bad & -2 \\
\hline \multirow[t]{5}{*}{ Assessment standard } & - & 70 & bad & -2 \\
\hline & 70 & 75 & under & -1 \\
\hline & 75 & 85 & normal & 0 \\
\hline & 85 & 90 & over & 1 \\
\hline & 90 & - & excellent & 2 \\
\hline \multirow[t]{5}{*}{ Absenteeism } & - & $4 \%$ & excellent & 2 \\
\hline & $4 \%$ & $7.5 \%$ & over & 1 \\
\hline & $7.5 \%$ & $8.5 \%$ & normal & 0 \\
\hline & $8.5 \%$ & $10 \%$ & under & -1 \\
\hline & $10 \%$ & - & bad & -2 \\
\hline
\end{tabular}

Table 7. Effectiveness performance classification $(\mathrm{EP}=$ effectiveness performance).

\begin{tabular}{ccccc}
\hline $\begin{array}{c}\text { Effectiveness } \\
\text { performance classes }\end{array}$ & under & normal & over & excellent \\
\cline { 1 - 3 } bad & & & \\
\hline $\mathrm{EP}<-30 \%$ & $\begin{array}{c}-30 \% \leq \mathrm{EP} \\
<-10 \%\end{array}$ & $\begin{array}{c}-10 \% \leq \mathrm{EP} \\
<10 \%\end{array}$ & $\begin{array}{c}10 \% \leq \mathrm{EP} \\
<0 \%\end{array}$ & $\mathrm{EP} \geq 30 \%$ \\
\hline
\end{tabular}

result may be classified based on the standardised percentage score.

\section{Relative Performance Score}

To be able to give a relative value now to the scores of 
the cases to be studied, we must place the total scores from such cases within the two extremes, best case and worst case (Table 8).

Table 8 provides an overall summary. The relationship between the effectiveness score and the standard range is expressed as a percentage thereof. The "normal" scores from cases $\mathrm{X}$ and $\mathrm{Y}$ are completely arbitrary and do not represent actual scores.

If, in the manner described above, the performance of companies is measured and placed within realistically selected extremes within the industry, a relative per- formance score will be obtained for the company or companies examined. Hence, as part of the measurement, all nominal and scalar characteristics are given a score. The final score will be determined by multiplying the value of each characteristic by the weight of the characteristic concerned. The scores thereby obtained for the various effectiveness criteria will then be added together to come up with a total score which falls within a certain range, with a related rating.

In Table 9, we have applied this method to a fictional example.

Table 8. Final comparison for effectiveness score.

\begin{tabular}{ccccccc}
\hline Case & Eff. Score & bad $-30 \%$ & under $-10 \%$ & normal $0 \%$ & over $10 \%$ & excellent $30 \%$ \\
\hline Best case & 56 & & & & \\
Case X & X\% & & & & \\
Case Y & Y\% & & & & \\
Worst case & -44 & & & & \\
\hline
\end{tabular}

Table 9. Scoring table for "De Eik" (best case).

\begin{tabular}{|c|c|c|c|c|}
\hline \multirow{2}{*}{ De Eik } & (Best Case) & \multirow{2}{*}{ Weight } & \multirow{2}{*}{ Score } & \\
\hline & Value & & & \\
\hline Financial added value & & 1 & 26 & 26 \\
\hline ROA & $21 \%$ & 5 & 10 & \\
\hline Labour ratio & $44 \%$ & 4 & 8 & \\
\hline Market share & Increase & 4 & 8 & \\
\hline Efficiency & & 1 & 26 & 26 \\
\hline Turnover rate & 5 & 4 & 8 & \\
\hline Days of receivables outstanding & 8 & 4 & 8 & \\
\hline ISO certification & Yes & 4 & 4 & \\
\hline Assessment standard & $91 \%$ & 3 & 6 & \\
\hline Needs met & & 1 & 9 & 9 \\
\hline Competitive price & Yes & 4 & 0 & \\
\hline Customer satisfaction & Yes & 5 & 0 & \\
\hline Delivery reliability & Yes & 5 & 0 & \\
\hline Just-In-Time deliveries & Yes & 5 & 5 & \\
\hline ISO certification & Yes & 4 & 4 & \\
\hline Self-maintenance & & 1 & 11 & 11 \\
\hline Organisational adjustment & Yes & 4 & 0 & \\
\hline Career management & Yes & 4 & 4 & \\
\hline New products & Yes & 4 & 4 & \\
\hline New services & Yes & 3 & 3 & \\
\hline Satisfaction & & 1 & 24 & 24 \\
\hline Salary & Collective labour agreement plus & 4 & 8 & \\
\hline Career management & Yes & 4 & 4 & \\
\hline Quality system & QM and ISO & 4 & 4 & \\
\hline Working conditions & Occupational health and safety plan & 4 & 0 & \\
\hline Absenteeism & $3 \%$ & 4 & 8 & \\
\hline Total score & & & & 96 \\
\hline
\end{tabular}


If, for example, we take a look at the effectiveness criterion financial added value, the total score of 26 was determined as follows:

- In the first column, " $21 \%$ " is shown for the scalar characteristic ROA (return on assets). This $21 \%$ is an excellent score within the industry and generates a score of 2 (see Table 7).

- Next, based on the benchmark, a weight of 5 (=very important) is assigned to this specific key indicator by experts [11].

- If we now multiply the ROA value from the first column in Table 9, namely, $2(21 \%=$ score 2$)$, by the score from the weight in column two, namely, 5, we get a score of $\mathbf{1 0}$ (column three).

- The same calculation method applies to the nominal characteristic market share in Table 9, which also falls within the effectiveness area financial added value, although the value of the concept 'increase' (of market share) here results in a score of 2. Market share increase is a three-category question generating $-1,1$ or 2 points for decrease, constant or increase respectively (see Table 4).

- When added together, all the scores in the financial added value effectiveness area in Table 9 result in a total score of 26.

- When added together, all the total scores in the different effectiveness areas result in a final score of $\mathbf{9 6}$ for 'De Eik'.

- This total score of 96 represents a maximum score (= $100 \%)$ as the best case.

- The same exercise for a fictional worst case results in a minimum score of $-74(=-/-100 \%)$. [12].

- The standard range [11] is thus 170 (distance between $-/-74$ and +96).

- Every 'real' case will therefore have a score somewhere within this standard range [11]. For instance, if a certain case results in an effectiveness score of 2 (= $-10 \%$ ), this case will fall within the 'under' classification (between $-10 \%$ and $10 \%$, see Table 7 ).

In principle, the performance of any for-profit company can be measured in this manner. Different effecttiveness characteristics with their own specific benchmarks may apply, though, to different industries and companies.

\section{The Performance of HRM}

After having presented a theoretical performance measurement model above which can be used to measure a for-profit company's overall performance, we will now adjust this model to measure the performance of personnel management, the purpose of this article. The model is essentially the same as the performance measurement model presented earlier. An additional element is the degree of influence which HRM can exert on the per- formance of the various performance characteristics.

To measure the performance of personnel management, we have to determine first the degree to which personnel management is capable of influencing the key effectiveness indicators formulated by us earlier. We need to bear in mind that it is nearly impossible to determine whether the key indicators or performance indicators used by us are in fact comprehensive enough [13,14].

Our key indicators can be considered actual indicators, that is, aspects of research objects which cannot be measured in a direct sense, but which can be considered key data or measured values based on which performance can be measured [15].

\section{The Degree of Influence Personnel Management has on the Key Effectiveness Indicators}

Because, as stated in Section 10, it is nearly impossible to determine precisely the degree to which personnel management influences the various key indicators, we used a simple five-point classification, in which the potential influence of personnel management on the particular key indicator is reflected as a percentage between $0 \%$ (not at all) and $100 \%$ (to the highest degree); see Table 10.

Table 10 below provides an overall summary of the key effectiveness indicators and the extent to which they are influenced by personnel management.

For purposes of the ultimate measurement of personnel management's performance, we will not include key indicators with a $0 \%$ score.

To assess personnel management's overall performance, we will use the same performance class classification as we used earlier to measure the company's overall performance (see Table 11).

Here, too, the performance measurement for personnel management is relative. Realistically selected scores for fictional best and worst cases indicate the extremes for bad and excellent performers respectively (see Table 11).

\section{HRM Performance Measurement: An Application}

A controller who is faced in practice with issues concerning HRM's effectiveness will, with the model presented here by us, be able to present a substantiated evaluation of the quality of the HR policy to his or her particular client. He or she will, however, have to adjust the model for each client and possibly for each industry; for different companies and/or industries, different performance indicators and key indicators are necessary to gain a proper picture of company performance and HRM performance. The performance areas or effectiveness 
Table 10. Degree to which key effectiveness indicator is subject to influence by personnel management, expressed as a percentage.

\begin{tabular}{|c|c|}
\hline Key effectiveness indicator & Degree influenced by personnel management \\
\hline \multicolumn{2}{|l|}{ Financial added value } \\
\hline ROA & $75 \%=$ to a high degree (direct) \\
\hline Labour ratio & $100 \%=$ to the highest degree (direct) \\
\hline Market share & $0 \%=$ not at all \\
\hline \multicolumn{2}{|l|}{ Efficiency } \\
\hline Stock turnover rate & $0 \%$ \\
\hline Days of receivables outstanding & $50 \%=$ to a certain extent (indirect $/$ direct) \\
\hline ISO certification & $25 \%=$ somewhat \\
\hline Assessment standard & $100 \%$ \\
\hline \multicolumn{2}{|l|}{ Needs met } \\
\hline Competitive price & $0 \%$ \\
\hline Customer satisfaction & $50 \%$ \\
\hline Delivery reliability & $0 \%$ \\
\hline Just-In-Time deliveries & $0 \%$ \\
\hline ISO certification & $25 \%$ \\
\hline \multicolumn{2}{|l|}{ Self-maintenance } \\
\hline Organisational adjustment & $75 \%$ \\
\hline Career management & $100 \%$ \\
\hline New products & $0 \%$ \\
\hline New services & $0 \%$ \\
\hline \multicolumn{2}{|l|}{ Satisfaction } \\
\hline Salary & $100 \%$ \\
\hline Career management & $100 \%$ \\
\hline Quality system & $25 \%$ \\
\hline Working conditions & $75 \%$ \\
\hline Absenteeism & $75 \%$ \\
\hline
\end{tabular}

Table 11. Effectiveness performance classification $(P=$ effectiveness performance).

\begin{tabular}{ccccc}
\hline HRM/PM performance classes & under & normal & over & excellent \\
\cline { 1 - 3 } bad & & & & \\
\hline $\mathrm{P}<-30 \%$ & $-30 \% \leq \mathrm{P}<-10 \%$ & $-10 \% \leq \mathrm{P}<10 \%$ & $10 \% \leq \mathrm{P}<30 \%$ & $\mathrm{P}[\geq] 30 \%$ \\
\hline
\end{tabular}

criteria financial added value, efficiency, needs met and self-maintenance will remain the same, at least for for-profit companies. Moreover, it is likely that other benchmarks will be needed and that the manner of formulating financial performance may differ by company. In the "Koninklijke Jongeneel" and "Houtgroep Van Drimmelen" cases studied by me, we used such key indicators as Return on Assets (ROA) for financial performance. Of course, it is a well-known fact that entirely different key indicators can also be utilised for financial performance. For meaningful comparisons to be made within an industry with regard to a specific company's financial performance, the indicators must therefore al- ways be adapted to a single manner of calculating profits. This will require some conversion work if companies within an industry use different methods to calculate profits. The various key indicators providing direction for a certain company can, of course, largely be taken from the annual financial and social reports. In addition, the controller will have to determine the benchmark for each key indicator. He or she can do this by, for example, having various experts within the industry concerned make a valuation for each key indicator. This will enable the controller to fill the model with relevant information, from which he or she can then ultimately quantitatively analyse the company's overall performance, and the 
HRM performance in particular, in the manner described by us in this article. Based on this analysis, the controller can advise the management of the company concerned as to which specific operational and HRM aspects must be given attention to, so that the company will be an $e x-$ cellent performer in the end.

It should be clear that, after such an analysis, the client must be consulted to determine the right strategy for boosting the effectiveness criteria and the related key indicators responsible for insufficient performance up to the right level. If, for example, an unfavourable ratio between personnel costs and gross profit (profit before taxes) appears to be a major cause of an insufficient return, the reasons for these high or excessive personnel costs will have to specifically be analysed further. For instance, the company in question may be utilising an assessment system which is not appropriate for this type of company. An industry which is sensitive to market fluctuations may, for example, have an assessment system which is rigid and inflationary and which is linked to a fixed remuneration system, in which too many 'good' evaluations drive up wages each year while the market does not afford much latitude for sufficient turnover growth. In such a case, implementing flexible remuneration for the commercial jobs may provide a solution. In another situation, if the number of days of receivables outstanding is too high, this may lead the company concerned to underperform. It must then be examined whether collection training for administrators can help lower this score, so that the company's profitability increases.

In short, the model offers enough insight into performance to be able to pinpoint, together with the board, the particular company's weaknesses and to provide this board with a well-founded recommendation concerning the action to be taken. In these discussions, maintaining a clear idea of the bottom-line objectives of the organisation in question is always critical.

\section{Concluding Remarks}

At the beginning of this article, it is said that there is a general assumption within the HRM literature that a positive relationship exists between HRM and corporate performance. It seems obvious that there is a relationship between HRM and performance, just as there is a relationship between financial management and performance or between logistical management and performance. Up to now, however, an empirically testable theoretical model to measure this relationship was lacking. It is only with such a model that HRM's role in the overall operations can be clarified, with the premise that HRM is one of the tools of management and not the pre-eminent tool for improving company performance. As is true for other management tools, HRM can have both positive and negative impacts on company performance. HRM should therefore not just be celebrated as a management tool, which seems to occur as a matter of course especially in the American literature [8-10,14], but can best be "simply" measured and then be assessed as to its quality within its own particular corporate context. This is the only way for HRM and personnel managers to get an idea of the HRM areas they must pay attention to, if they want to be able at all to make a favourable contribution to their companies' bottom-line objectives.

The questions we pose at the start, to wit: "is the performance of HRM/PM measurable and can it be assessed quantitatively and are we capable of developing a practical tool enabling controllers to furnish their clients with useful advice in practice concerning the HRM policy to be followed?" now can be answered with a "yes".

\section{REFERENCES}

[1] G. R. A. de Jong, "Effectief Personeelsmanagement, Een Interventiestrategie," 2nd Edition, Deventer, Kluwer, 1988.

[2] A. Th. Leijten, "Stimulerend Personeelsmanagement, Een Interventiestrategie," Dissertation, Universiteit Twente, 1991.

[3] J. Leget, "Personeelbeleid en Succes van Organisaties. Resultaatgericht Human Resource Management in Nederland," Kluwer, Deventer, 1997.

[4] J. Paauwe, "HRM and Performance: The Linkage between Resources and Institutional Context. Unique Approaches in Order to Achieve Competitive Advantage," Discussion, BathUniversity, 1996.

[5] R. C. H. van Otterlo, "De Invloed van Personeels Management op de Prestatie van ondernemingen. Een Theoretisch-Empirisch Onderzoek Naar de Mate van Succes van Personeels Management in Traditionele Bedrijven Binnen de Profit-Sector," Dissertation, Vrije Universiteit, Amsterdam, 1999.

[6] G. R. A. de Jong, "Effectief Personeelsmangement. Een interventiestrategie," 2nd edition, Kluwer, Deventer, 1988.

[7] A. Th. Leijten, "Stimulerend Personeelsmanagement. Een Effectiviteitsdiagnose," Tilburg University, Dissertation, Amsterdam, 1991.

[8] J. B. Arthur, "The Effects of Human Resource Systems on Manufacturing Performance and Turn-Over," The Academy of Management Journal, Vol. 37, No. 3, 1994, pp. 670-687.

[9] M. A. Huselid, "The Impact of Human Resource Management Practices on Turnover, Productivity, and Corporate Financial Performance," Academy of Management Journal, Vol. 38, No. 3, 1995, pp. 635-672.

[10] D. E. Guest, "Human Resource Management and Performance: A Review and Research Agenda," The International Journal of Human Resource Management, Vol. 8, No. 3-6, 1997, pp. 263-276.

[11] R. C. H. van Otterlo, "De Invloed van Personeels- 
management op de Prestatie van Onderne-Mingen. Een Theoretisch-Empirisch Onderzoek Naar de Mate van Succes van Personeelsmanagement in Traditionele Bedrijven Binnen de Profit-Sector," Dissertation, Vrije Universiteit, Amsterdam, 1999.

[12] R. C. H. van Otterlo, "De Invloed van Personeelsmanagement op de Prestatie van Onderne-Mingen. Een Theoretisch-Empirisch Onderzoek Naar de Mate van Succes van Personeelsmanagement in Traditionele Bedrijven Binnen de Profit-Sector," Dissertation, Vrije Universiteit, Amsterdam, 1999, pp. 115-116.

[13] P. R. Baarda, C. P. M. Kouwenhoven and J. A. Werkhoven, "Kenenstuurgetallen voor Personeelsmanagement.
Cijfers Voor Diagnose en Besturing," Kluwer, Deventer, 1994, p. 52.

[14] A. S. Tsui and L. R. Gomez-Mejia, "Evaluating Human Resource Effectiveness," In: L. Dyer, Ed., Human Resource Management Evolving Roles and Responsibilities, The Bureau of National Affairs, Washington DC, 1988, pp. 187-227.

[15] W. Mastenbroek, "Verandermanagement. Sturen op Verantwoordelijkheid. Resultaatverbetering Door Meer Zelforganisatie én Betere Sturing. Organisatievernieuwing als Relatie-Management. Bestuurlijke Civilisatie en Gedrags-Verandering," Holland Business Publications, Heemstede, 1997. 